\title{
PAJJAPPI (MANTRA) SEBAGAI PENGOBATAN TRADISIONAL MASYARAKAT BUGIS DI DESA BILA
}

\author{
Nur Arfina Febriani 1 \\ 1 Program Studi Pendidikan Antropologi, Universitas Negeri Makassar \\ Korespondensi: arfinafebriani@gmail.com
}

\begin{abstract}
The purpose of this study was to find out the meaning of illness and health for the Bugis people in Bila village, the meaning of the word Pajjappi in the process of traditional medicine and the community's belief in this traditional medicine. This research uses a qualitative approach and the type of research method is ethnographic research methods, testing the validity of the data using qualitative data analysis techniques. The interpretive theory in this study is used to analyze the definitions of meaningful practice. Until the data collection technique used is by means of interviews and observations. From the research results obtained indicate that the effort to cure the disease experienced by the community is determined from the cause of the disease, whether the pain felt is reasonable or not depending on the individual. The greater the pain felt, the greater the search for suitable treatment. So that people know the term "match" in treatment. This means that they will continue to seek treatment with various kinds of traditional medicine. Then the meaning of sick and healthy for the local community. According to the informant, healthy is when we do not feel pain or any complaints on him so that he can carry out activities as usual. Then pain is defined as when there is a loss of passion for work, loss of appetite, and a disturbed mind or mind. Furthermore, the methods used by shamans or smart people in the process of healing diseases sometimes use media or not, returning to the knowledge of the shaman. Diseases that are medical (naturistic) or personalistic in nature, sometimes shamans use media such as water, sometimes they don't use media at all, depending on the knowledge the shaman has acquired.
\end{abstract}

Keywords: Traditional Medicine, disease, meaning 
Aceh Anthropological Journal,

Abstrak: Tujuan dari penelitian ini adalah untuk mengetahui secara makna dari sakit dan sehat bagi masyarakat Bugis di desa Bila, makna dari kata Pajjappi dalam proses pengobatan tradisional serta keperyaan masyarakat terhadap pengobatan tradisonal tersebut. Pada penelitian ini menggunakan pendekatan kualitatif dan jenis metode penelitian yakni metode penelitian etnografi, pengujian keberanaran data menggunakan teknik analasis data kualitatif. Teori interpretatif pada penelitian ini digunakan untuk menganalisis definisi-definisi praktik yang bermakna. Hingga teknik pengumulan data yang digunakan yakni dengan cara wawancara dan observasi. Dari hasil penelitian yang diperoleh menunjukkan bahwa upaya penyembuhan penyakit yang dialami oleh masyarakat ditentukan dari penyebab penyakit tersebut apakah rasa sakit yang dirasakan wajar atau tidak tergantung dari Individu. Semakin besar rasa sakit yang dirasakan maka semakin besar pula mencari pengobatan yang cocok. Sehingga masyarakat mengenal istilah "cocok-cocokan" dalam pengobatan. Artinya mereka akan terus berusaha untuk mencari pengobatan dengan berbagai macam pengobatan tradisional. Kemudian pemaknaan dari sakit dan sehat bagi masyarakat setempat. Menurut informan sehat adalah ketika kita tidak merasakan sakit atau keluhan apapun pada dirinya sehingga bisa melakukan aktifitas seperti biasanya. Kemudian sakit didefinisikan sebagai ketika kehilangan gairah bekerja, hilangnya nafsu makan, serta batinatau pikiran yang terganggu. Selanjutnya metode yang digunakan oleh dukun atau orang pintar dalam proses penyembuhan penyakit terkadang menggunakan media ataupun tidak, kembali lagi ke pengetahuan dukun tersebut. Penyakit yang bersifat medis (naturlistik) atau penyakit yang bersifat Personalistik terkadang dukun menggunakan media seperti air putih kadang juga tidak menggunakan media sama sekali tergantung dari pengetahuan yang diperoleh dukun tersebut.

Kata Kunci: Pengobatan Tradisional, penyakit, makna 


\section{A. Pendahuluan}

Pada saat sekarang ini sistem pengobatan telah berkembang pesat dan hampir menyentuh seluruh lapisan masyarakat baik itu di perkotaan maupun pedesaan seiring dengan berkembangnya ilmu pengetahuan, teknologi, farmasi serta kedokteran. Sistem pengobatan yang terus berkembang pasti selalu dibarengi dengan berkembangnya praktik-praktik pengobatan tradisional. Hal ini menunjukkan bahwa masih hidupnya sistem pengobatan tradisional dan menjadi model pengobatan secara tradisional sampai saat ini di dalam masyarakat.

Keberagaman budaya, etnis, adat-istiadat, serta kepercayaan di Indonesia membuat berbagai keberagaman tradisi dalam proses pengobatan tradisional. Pengobatan tradisional masih sering di jumpai pada masyarakat pedesaan, pengobatan tersebut sangat berpengaruh dalam pelayanan kesehatan masyarakat seperti yang terdapat di desa Bila yang menggunakan Pajjappi sebagai pengobatan tradisional. Melalui pengobatan ini, masyarakat dapat mengetahui keadaan sakit atau tidak sakitnya melalui praktik-praktik yang ada di masyarakat tergantung kepercayaannya.

Sistem pengobatan termasuk dalam sistem pengetahuan yang dimiliki suatu bangsa yang dalam praktiknya dapat di masukkan dalam unsur teknologi. Kebudayaan masyarakat Bugis dalam pengobatan tradisional sudah ada sejak puluhan tahun bahkan ratusan tahun yang lalu, yakni sebelum masuknya teknik pengobatan modern seperti saat ini.

Sistem pengetahuan yang ada dalam setiap kebudayaan pasti mempunyai batasan kemampuannya sendiri, sehingga setiap kebudayaan mempunyai capaian yang berbeda. Keinginan yang muncul dari diri individu untuk sehat menimbulkan keinginann masyarakat untuk mendapatkan berbagai pengobatan agar memperoleh kesembuhan walaupun sistem pengobatan tersebut terkadang tidak irasional. Pemilihan pengobatan tersebut dipilih atas dasar hilangnya harapan karena pengobatan yang telah dilakukan tidak kunjung sembuh sehingga individu melakukan berbagai alternatif walaupun itu bentuknya magis.

Pengobatan tradisional ini masih terus ada di dalam kehidupan bermasyarakat meskipun sistem pengobatan yang lebih modern telah dikenal luas 
oleh masyarakat baik itu masyarakat di perkotaan maupun masyarakat di pedesaan. Pengobatan tradisional yang dimaksud adalah pengobatan yang dari nenek moyang yang diwariskan secara turun-temurun untuk penyembuhaan terhadap penyakit atau pengetahuan dengan menggunakan bahan-bahan alam.

Pada umumnya proses penyembuhan pengobatan tradisional di desa Bila di kategorikan dalam pengobatan menggunakan ramuan obat-obatan tradisional (alam). Sedangkan untuk penyembuhan dengan cara spiritual menggunakan doadoa atau matera-matera yang dibacakan oleh dukun atau orang pintar. Orang yang melakukan praktik-praktik tersebut selalu memerhatikan latar belakang orang yang ingin disebuhkan seperti tadisi, keluarga, kepercayaan dan lain sebagainya. Ciri pelayanannya seperti akrab, ramah, sabar serta pasrah kepada Tuhan atau kepada hal-hal gaib yang mereka percaya. Biayanya pun pada umumnya relatif terjangkau, tapi kembali lagi ke individu yang melakukan pengobatan.

Pada umumnya masyarakat Bugis yang masih berobat ke dokter pun masih sering menggunakan jasa orang pintar untuk menyembuhkan penyakit yang tidak bisa disebuhkan secara medis. Yang pernah berobat keorang pintarpun bukan hanya yang bersal dari kalangan bawah, tapi mereka juga yang berasal dari kalangan menengah ke atas. Di desa Bila contohnya, pengobatan oleh dukun merupakan sesuatu yang sulit untuk dipisahkan oleh masyarakat dan telah menjadi budaya serta tradisi di lingkungannya.

Masyarakat di desa Bila mengenal sistem pengobatan yang dilakukan secara non medis atau magis masih bersifat tradisional, yakni masih banyak menggunakan jasa orang pintar dalam mengobati suatu penyakit walaupun sudah banyak pelayanan kesehatan secara medis yang tersedia di masyarakat. Bahkan dukun yang dipercayai pada masyarakat setempat dan tidak hanya masyarakt setempat. Jasa mereka maish sangat dibutuhkan sampai saat ini walaupun layanan kesehatan saat ini sudah terbilang sangat memadai untuk pertolongan pada masyarakat.

Pertolongan seorang dukun atau yang sering disebut dengn orang pintar bukan hanya sebatas pada penyembuhan secara fisik melainkan juga penyembuhan secara spiritual walaupun obat-obatan serta alat yang diberikan oleh dukun terbilang sederhana. Penyembuhan penyakit dalam suatu kelompok 
masyarakat berlaku cara-cara tertentu tergantung dari kepercayaan masyarakat tersebut seperti yang ada di desa Bila menggunakan metode pengobatan dengancara ramuan tradisional, mantera, air putih yang sudah di doakan atau majjappi.

Dengan demikian, penjelasan singkat tentang yang melatar belakang penelitian sangat menarik sekali untuk diteliti pengobatan yang ada di desa Bila ini dengan menggunakan metode penelitian etnografi membahas secara mendalam tentang praktik-praktik pengobatan tradisonal. Untuk itu, berdasar dari latar belakang yang dijelaskan maka, sangat perlu untuk mengkaji lebih dalam secara ilmiah yang terkandung dalam pengobatan yang menggunakan metode pajjappi' dengan membacakan matera atau doa-doa yang disebut dengan pajjappi dan memahami apa yang masih mengaruhi kepercayaan masyarakat terhadap pengobatan tradisional tersebut.

\section{B. Metode Kajian}

Metodelogi etnografi adalah ilmu tentang metode etnopgrafi, sedangkan metode etnografi adalah strategi pencapaian ke etnografi dalam mendeskripsikan sesuatu dari lapangan penelitian atau sejenisnya. Metode etnografi adalah salah satu desain dari penelitian kualitatf antropologi, penelitiannya mendefinisikan serta menafsirkan pola dari bahasa, perilaku, nilai dan keyakinan dari suatu kelompok yang mempunyai kebudayaan yang sama. Sekaligus merupakan hasil riset, etnografi juga merupakan cara untuk mempelajari sebuah kelompok yang berbudaya. Sedangkan etnografi juga melibatkan si peneliti untuk melakukan penelitian terhadap hal yang lebih luas pada kelompok yang berbudayaan tersebut.

Proses pengumpulan data dalam penelitian kualitatif ini pada umumnya menggunakan teknik wawancara dan obsevasi. Pada dasarnya observasi adalah kegiatan yang mmelibatkan panca indera seperti pengelihatan, pendengaran atau penciuman yang berguna untuk memperoleh informasi untuk menjawab persoalan-persoalan yang ada, hasil observasinya berupa kejadian,peristiwa, fenomena, objek atau kondisi serta suasana. Observasi dilakukan untuk 
memperoleh gambaran rill suatu gejala-gejala untuk menjawab ermasalahan dari peneliti.

Menurut Bungin (2007: 115-117) observasi diklasifikasikan kedalam beberapa bentuk yakni observasi kelompok, observasi partisipan, dan observasi tidak terstruktur. Dalam penelitian ini lebih mengarah ke metode penelitian observasi partisipan karena pada saat proses penelitian ini berlangsung peneliti terjun langsung kelapangan, mengamati apa yang terjadi dilapangan dan melihat secara langsung proses pengobatan serta praktik-praktik pengobatan yang dilakukan di lapangan.

Teknik pengumpulan data yang dilakukan lainnya yaitu dengan mewawancarai informan. Wawancara merupakan proses interaksi dengan informan untuk mengumpulkan informasi secara tanya jawab antara peneliti dengan informan. Wawancara dilaksanakan setelah orang pintar tersebut melakukan proses pengobatan. Selama proses pengobatan tersebut peneliti melakukan pengamatan, dan menanyakan secara langsung apa saja yang dilakukan dukun tersebut dalam pengobatan pasiennya. Selain itu peneliti juga mewawancari pasien yang datang untuk melakukan pengobatan setelah proses pengobatan itu selesai dilakukan oleh orang pintar tersebut.

\section{Proses Seseorang Bisa Melakukan Pengobatan}

Seseorang bisa melakukan pengobatan karena pewarisan dari orang tua atau nenek moyangnya yang sebelumnya orang pintar atau dukun. Anak yang diwarisi kemampuan orang tuanya dianggap sebagai "anak pilihan" karena tidak semua anak bisa mewarisi kemampuan orang tuanyatersebut. Artinya, walaupun ada keluarga yang memiliki 6 anak, tapi tidak semua anak itu akan mengikuti jejek orang tuanya sebagai dukun. Hanya salah satu diantara mereka yang terpilih.

Seperti halnya Pak Arif, yang pada awalnya tidak percaya akan hal yang supranatural. Beliau baru menyadari dirinya bisa menyembuhkan orang lain ketika kakeknya telah meninggal. Selama hidup kakeknya, tidak pernah mengajari atau berguru tentang hal tersebut. Tapi setelah pak Arif percaya akan hal yang 
supranatural ia pun baru mengasah kemampuannya secara diam-diam dengan bimbingan orang lain. Berikut pernyataan pak Arif tentang hal tersebut.

"Dulu waktu kakekku hidup, dia tidak pernah mengajari saya untuk mengobati orang. Tapi setelah dia tiada,saya baru dapat mimpi-mimpi, yang paling saya ingat itu ketika saya lihat bintang, bulan dan matahari selurus dan bisa bicara. Sejak itu saya bertanya dengan om saya yang lebih mengerti tentang hal seperti itu, Om saya bilangitu tanda kalau saya punya kelebihan dalam artian supranatural tapi perlu diasah lagi"

Kemudian, Pak Arif pun memakai media air putih kemudian di jjappi menggunakan mantera-mantera yang didapatkan untuk mengobati penyakit yang diderita pasien. Metode pengobatan air putih yang dijjappi saling berhubungan dengan penyakit medis maupun penyakit non-medis. Jika pasien menderita penyakit non medis sekaligus penyakit medis maka dilakukan terapi agar saling melengkapi.

\section{Pengertian Sehat dan Sakit bagi Masyarakat}

Pemahaman masyarakat tentang anatara sehat dan juga sakit memiliki kesamaan yakni dimana masyarakat yang bersedia menjadi informan dalam penelitian ini mengatakan bahwa sehat adalah ketika kondisi tubuh tidak mengalami keluhan dan bisa menjalankan aktivitas seperti biasanya kemudian, sakit menurut mereka adalah ketika kehilangan semangat untuk melakukan pekerjaan, hilangnya nafsu makan, bahkan pikiran dan juga batin yang ikut terganggu.

Secara umum sehat yang digambarkan masyarakat yakni ketika mampu menjalankan aktifitas seperti biasanya. Ketika mereka merasakan ada keluhan dan tidak mampu menjalankan aktifitas maka itu di anggap sebagai sakit. Tapi sakit bukan hanya secara secara fisik melainkan juga secara batin.

Penyebab sakit adalah satu hal yang tidak boleh diabaikan agar bisa mengetahaui apa yang akan dilakukan selanjutnya. Masyarakat Bugis membedakan sakit dengan 2 kategori yakni sakit yang wajar dan sakit yang tidak wajar. Sakit yang tidak tidak wajar disebabkan oleh sesuatu yang tidak alamiah, ketika penyakit tersebut tidak rasional maka dikatakan sebagai penyakit yang tidak wajar begitupun sebaliknya. 
Seperti yang dikatakan oleh salah satu informan kami yaitu Bu Anti pada saat setelah melakukan pengobatan :

"Saya sudah sangat lama sakit dek, sudah kemana-mana berobat baik itu dokter ataupun pengobatan alternatif pun tapi belum sembuh juga, kalau mau berjalan pun susah. Saya juga selalu terbawa emosi, kalau orang lain liat saya saja langsung marah termasuk orang-orang di rumah saya kadang marah-marah tidak jelas. Setelah tau ada pengobatan ini, sayapun langsung ke sini dan berharap semoga cocok dengan yang disini. Alhamdulillah sudah hampir enam bulan berobat disini sudah banyak perubahan yang saya rasakan, saya sudah mampu mengontrol emosi, sudah bisa berjalan dan sudah bisa bekerja".

Ketika seseorang sembuh dari penyakitnya, jika ia sakit lagi maka mereka akan kembali melakukan pengobatan dimana merek sembuh dulunya. Namun jika seseorang belum mendapatkan kesembuhan dari tindakan yang diambilnya, maka ia akan terus mencari upaya lain untuk pengobatan atau masyarakat disini menyebutnya cocok-cocokan.

Masyarakat tradisonal berandangan bahwa orang yang sakit adalah seseorang kehilangan semangat kerja dan kehilangan nafsu makan serta menurunnya kekuatan sehingga hanya mampu berbaring. Usaha untuk sembuh dan mencari pengobatan yang cocok sangat penting. Jika gejala penyakitnya tergolong ringan maka pengobatan yang dilakukan yakni mengobati sendiri atau bahkan menunda pengobatan berharap masih bisa sembuh dengan sendirinya. Tetapi jika penyakit yang dirasa sudah mengacam jiwanya, contohnya gangguan akibat hal gaib atau rasa sakit yang di rasakan tidak tertahankan lagi maka pihak dari keluarga atau lingkungannya akan mencari pengobatan sesuai dengan keyanian mereka.

\section{E. Makna Pajjappi dalam Pengobatan Tradisional}

Pengobatan menggunakan metode pajjappi digunakan untuk pasien yang terkena penyakit non medis seperti guna-guna, santet, kemasukan jin, melunturkan ilmu, membuang jimat atau teluh dimana hal-hal tersebut penyebab dari penyakit karenak campur tangan hal-hal yang bersifat mistis yang mengganggu batin seseorang. Artinya, jika dilihat secara fisik orang yang terkena 
gangguan tersebut mereka akan sehat tapi secara batin mereka sakit. Pasien yang terkena pengobatan menggunakan pajjappi bisa tergolong penyakit yang biasa, cukup parah bahkan sangat parah tergantung dari gejala-gejala yang dirasakan.

Selain digunakan sebagai pengobatan, pajjappi sendiri punya arti tersirat bagi penggunanya. Sangat penting untuk mengetahui makna yang terkandung karena kajian sosial itu mencari intepretasi dari praktik manusia yang bermakna. Adapun makna yang dikatakan oleh Pak arif pada saat wawancara :

"Sebenarnya ada makna tersendrinya itu pajjappi kalau dari ilmu supranatural. Berdasarkan pandngan supranatural pajjappi ini mampu mencegah dan menetralkan hal-hal yang bersifat gaib seperti kiriman dari orang-orang akan berbalik ke orang yang mengirimi itu karena sudah dipagari dengandoa-doa. Kemudian pajjappi itu hanya sebutan untuk mengobati orang-orang dengan doa-doa atau matera-matera yang kami daptkan atau kami pelajari."

Berdasarkan hasil wawancara di atas diketahui mengapa menggunakan metode pajjappi. Dimana dalam keseharian masyarakat sering menyebutnya sebagai pajjappi yang memiliki pandangan supranatural untuk mencegah hal-hal yang tdak kasat mata sehingga mampu menetralkan penyakit-penyakit sihir atau guna-guna.

\section{F. Kesimpulan dan Saran}

Hasil hasil pengumpulan data yang dilakukan dapat ditarik beberapa kesimpulan yaitu, a) Proses seorang dukun atau orang pintarmampu melakukan pengobatan karena mewarisi pengetahuan dari orang tua atau nenek moyangnya. Anak yang mewarisi kemampuan tersebut adalah anak pilihan dimana tidak semua anak mampu mewarisi kemampuan orang tuanya tersebut dalam proses pengobatan, b) ada dua metode yang digunakan dalam praktik pengobatan yakni dengan pajjappi menggunakan media air putih atau langsung dijjappi oleh orang pintar tersebut, c) dalam melakukan pengobatan masyarakt mengenalnya dengan istilah "cocok-cocokan" artinya mereka berusaha menyembuhkan penyakit yang mereka derita dengan menggunakan berbagai alternatif. Ketika pasien ingin berobat mereka mengatakan semoga saja cocok dengan pengobatan disini artinya semoga penyakitnya bisa disembuhkan oleh dukun atau orang pintar di mana 
tempat mereka berobat. Jika dalam proses pengobatan belum kunjung sembuh maka mereka akan mencari lagi tempat pengobatan yang lainnya dan berharap cocok dengan pengobatan tersebut. Istilah cocok-cocokan ini membuat masyarakat pantang menyerah untuk mencari pengobatan sampai menemukan yang cocok dan sembuh dari penyakitnya, d) pengertian sehat dan sakit menurut masyarakat memiliki kesamaan dimana masyarakat yang bersedia menjadi informan dalam peneltian ini mengatakan sehat adalah ketika kita tidak merasakan adanya keluhan atau gejala oleh tubuh dan bisa melakukan aktivitas seperti biasanya kemudian, sakit dijelaskan bahwa ketika hilangnya semangat kerja atau hilangnya nafsu makan serta terganggunya pikiran atau batin, e) makna pajjapi yang digunakan dalam pengobatan dimaksudkan bahwa mampu menetralkan hal-hal yang bersifat gaib, selain sifatnya yang mampu menetralkan hal-hal gaib bisa juga digunakan sebagai pagar agar terhindar dari hal-hal yang bersifat supranatural.

Berdasarkan hal yang diperoleh dari penelitian ini maka penulis memberikan beberapa saran yakni a) pengobatan tradisional ini adalah pengobatan yang di wariskan secara turun-temurun. Pengobatan tersebut merupakan kekayaan budaya tersendiri bagi suatu kelompok masyarakat atau suku. Oleh sebab itu, peneliti perlu mengetahui secara dalam tentang pengobatan tradisional, serta didokumentasikan dalam bentuk tulisan agar pengetahuan tersebut tidak hilang dari masyarakat karena pengaruh dari luar, b) pengetahuan tentang pengobatan secara tradisional dapat digunakan untuk berbagai penyakit, termasuk penyakit yang tidak mampu disembuhkan oleh medis sehingga perlu mempertimbangkan untuk melakukan pengobatan tradisonal, c) bagi pemerintah sebaiknya perlu melakukan bimbingan serta pengawasan terhadap praktekpraktek yang melakukan pengobatan tradisonal, d) untuk peneliti selanjutnya yang mengambil judul yang serupa agar lebih disempurnakan lagi karena masih banyak hal yang perlu diungkap dalam masalah ini. Serta penelitian ini dijadikan tolak ukur untuk penelitian selanjutnya. 


\section{Daftar Pustaka}

Burgin, Burhan. 2007. Metodologi Penelitian Kualitatif, Jakarta : PT Raja Grafindo Persada.

Burgin, Burhan. 2007. Penelitian Kualitatif: Komunikasi, Ekonomi, Kebijakan Publik, dan Ilmu Sosial Lainnya. Jakarta: Kencana Prenada Media Group.

Foster dan Anderson. 1986. Antropologi Kesehatan. Terjemahan oleh Priyani Pakan Suyadarma. Jakarta: UI-Press.

Koentjaraningrat. 2000. Pengantar Ilmu Antropologi. Jakarta: Radar Jaya Offset.

Moleong, Lexi J. 2011. Metodologi Penelitian Kualitatif (Konsep Dasar Penelitian Kualitatif). Bandung: Remaja Rosdakarya, (edisi revisi).

Soejoeti, Sunanti Z. 2010. Konsep Sehat, Sakit dan Penyakit dalam Konteks Sosial Budaya. Pusat Penelitian Ekologi Kesehatan, Badan Penelitian dan Pengemangan Kesehatan. Jakarta: Departemen Kesehatan RI. 